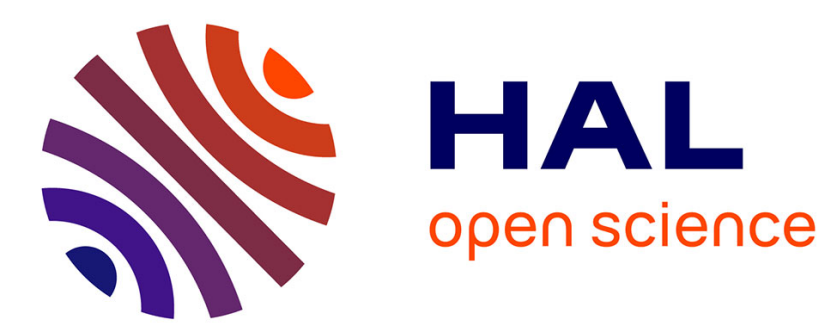

\title{
Productivity, networks, and export performance: evidence from a cross-country fi rm dataset
}

\author{
Luca Antonio Ricci, Federico Trionfetti
}

\section{To cite this version:}

Luca Antonio Ricci, Federico Trionfetti. Productivity, networks, and export performance: evidence from a cross-country fi rm dataset. 2011. halshs-00633033

\section{HAL Id: halshs-00633033 \\ https://shs.hal.science/halshs-00633033}

Preprint submitted on 17 Oct 2011

HAL is a multi-disciplinary open access archive for the deposit and dissemination of scientific research documents, whether they are published or not. The documents may come from teaching and research institutions in France or abroad, or from public or private research centers.
L'archive ouverte pluridisciplinaire $\mathbf{H A L}$, est destinée au dépôt et à la diffusion de documents scientifiques de niveau recherche, publiés ou non, émanant des établissements d'enseignement et de recherche français ou étrangers, des laboratoires publics ou privés. 


\section{GREQAM}

Groupement de Recherche en Economie Quantitative d'Aix-Marseille - UMR-CNRS 6579

Ecole des Hautes études en Sciences Sociales Universités d'Aix-Marseille II et III
Document de Travail $n^{\circ} 2011-42$

Productivity, networks, and export performance: evidence from a cross-country firm dataset

Luca Antonio Ricci Federico Trionfetti

October 2011 


\title{
Productivity, networks, and export performance: evidence from a cross-country firm dataset *
}

\author{
Luca Antonio Ricci ${ }^{\dagger} \quad$ Federico Trionfetti ${ }^{\ddagger}$
}

October 17, 2011

\begin{abstract}
This paper uses a newly assembled multi-country multi-industry firm-level dataset to test the effect of productivity and networking on the export probability of firms. Results are in line with the new-new trade theory and with the literature on the information value of networks. Firms are more likely to export if they are more productive, larger, and if they benefit from foreign networks (ownership and financial linkages), domestic networks (chamber of commerce, links to regulation), and communication networks (E-mail, internet). Firms bear a lower probability of exporting if they have state or labor networks. Overall, firms with better network connections by one standard deviation enjoy a $15 \%$ higher probability of exporting.
\end{abstract}

JEL codes: F11, F12, F14

Keywords: new-new trade theory, export probability

${ }^{*}$ We thank Donald Davis, Giuseppe De Arcangelis, Pravin Krishna, Peter Schott, the referees, and the participants in the conference in honor of Giancarlo Gandolfo for very helpful discussions. Fei Liu, Maria Victoria Fazio, and Utsav Kumar provided excellent research assistance. A special thank to Mary Hallward-Driemeier for pointing us to this rich dataset. This paper should not be reported as representing the views of the IMF. The views expressed in this paper are those of the authors and do not necessarily represent those of the IMF or IMF policy.

${ }^{\dagger}$ International Monetary Fund, Research Department. Email: LRicci@imf.org

${ }^{\ddagger}$ Aix-Marseille Université, AMSE (GREQAM). Email: Federico.Trionfetti@univmed.fr 


\section{Introduction}

Even a cursory glance at the data reveals that not all firms are engaged in international trade. This diversified reality about the export performance of firms has recently found a theoretical collocation in general equilibrium models such are those proposed by Bernard, Eaton, Jensen, and Kortum (2003) and Melitz (2003), which rely mainly on firms' heterogeneity in productivity. The positive effect of productivity on the probability of exporting is well documented in many studies. Evidence in this sense is found inter alia in Aitken, Hanson and Harrison (1997), Roberts and Tybout (1997), Bernard and Jensen $(1999,2004)$. Our results confirm that the probability of exporting is increasing with productivity using firm level data from many countries and sectors.

A different strand of literature has studied the role of networks in facilitating international trade; see, e.g., Rodrick (2000), Rauch (2001), Casella and Rauch (2002), Rauch and Trindade (2002), Wagner, Head, and Ries (2002), Rauch and Casella (2003), Combes, Lafourcade and Mayer (2005). Networks and connections reduce the disadvantage presented by informational barriers, and hence reduce the cost of economic transactions. In line with this literature, we find that firms are more likely to export if they benefit from foreign networks (ownership and financial linkages), domestic networks (chamber of commerce, links to regulation), communication networks (E-mail, internet). Firms bear instead a lower probability of exporting if they are affected by state or labor networks.

Our results suggest a possible link between the two literatures cited above. In the first literature, productivity and the fixed exporting cost are the key factors generating the partition between exporters and non exporters. For a given fixed exporting cost, the higher the firm productivity the more likely is that the firm exports; for a given level of firm productivity, the lower the fixed exporting cost faced by the firm the more likely it is that the firm exports. In the second literature, the barrier to international trade is typically informational (the cost of acquiring knowledge about foreign suppliers, foreign consumers, foreign business and regulation practices, and the cul- 
tural environment in general). These informational barriers may be seen as a form of fixed exporting cost. Thus, one may postulate that foreign network connection reduce fixed exporting costs thereby increasing the probability of exporting. We are agnostic as to whether this is indeed the causal chain but the empirical evidence gives plausibility to this hypothesis opens the way to interesting research avenues.

The remainder of the paper is as follows. Section 2 derives the estimated relationships, Section 3 presents the data, Section 4 shows the empirical results, and Section 5 concludes.

\section{Estimated relationship}

In this section we draw two empirically verifiable conclusions from the reading of the theoretical literature.

In theoretical models in the vein of Melitz (2003), a firm exports if foreign profits are non-negative and does not export otherwise. Foreign profits are given by foreign revenues minus variable cost (including variable trade cost), minus fixed exporting cost. Foreign revenues increase with productivity and variable cost decrease with productivity. Therefore, for given fixed exporting cost:

1. the probability of exporting is increasing with firm productivity.

In the theoretical literature on networks a reduction in informational barriers increases international trade (possibly because they have lower fixed exporting cost). This possible link between fixed exporting costs and informational barriers is suggestive but not crucial for our purposes. From the literature on networks we simply draw that

2. a firm with better networking connections has a higher probability of exporting.

These two conclusions may be summarized in the following relationships to be tested empirically: 
The empirical methodology adopts the following probit regression of the export dummy $\Psi_{c i j}$ for firm $j$ in industry $i$ of country $c$.

$$
\Psi_{c i j}=\varsigma_{i c}+\xi X_{c i j}+\epsilon_{c i j}
$$

The dependent variable is regressed on various determinants $X_{c i j}$ : productivity, employment, and variables related to firms' connections to networks. Regressions include country-industry fixed effects to control for omitted variables which are specific to each sector in each country, and are estimated with robust standard errors.

\section{Data description}

We use the Enterprise Survey firm-level dataset which is based on a World Bank survey of a representative sample of an economy's private sector. The surveys cover a broad range of business environment topics including infrastructure, crime, competition, access to finance, corruption, and performance measures. ${ }^{1}$

We derive an export dummy (=1 if the firm exports, and 0 otherwise) from the information on whether the firm exports. Tables 1 and 2 present the percentage of firms that export, by country and by industry respectively. Note that about 30 percent of firms in our sample are exporters but the percentage is 8 percent for smaller firms, is about 25 percent for medium size

\footnotetext{
${ }^{1}$ The survey is conducted by private contractors and is answered by business owners and top managers. "The manufacturing and services sectors are the primary business sectors of interest. This corresponds to firms classified with ISIC codes 15-37, 45, 50-52, 55, 60-64, and 72 (ISIC Rev.3.1). ... Formal (registered) companies with 5 or more employees are targeted for interview. Services firms include construction, retail, wholesale, hotels, restaurants, transport, storage, communications, and IT. Firms with 100\% government/state ownership are not eligible to participate in an Enterprise Survey. ... In each country, businesses in the cities/regions of major economic activity are interviewed." (http://www.enterprisesurveys.org/Methodology/).
} 
firms, and is 51 percent for larger firms.

[TABLE 1 AND 2 HERE]

Productivity is proxied by the ratio of sales to employment, in log terms, which is commonly used when total factor productivity is not available (sales are converted in US. $\$$ in order to make them comparable across countries). ${ }^{2}$ We also add employment as a proxy for firms' size.

There is no standard way to measure all possible network connections which influence firms' economic activity. Within the economic indicators available in the dataset we use the following variables: "Firms is in a joint venture", "Firms uses E-mail", "Firm has website", and "Firm belongs to a chamber of commerce", which are dummy variables: 1 if the firm does, 0 otherwise. "Foreign financing", which is measured by the percentage of working capital financed by foreign-owned banks. "Foreign participation", which is measured by the percentage of the firm owned by foreign private sector. "Time spent with gov't regulations", which is measured by the percentage of senior management's time spend dealing with government regulations. "State participation", which is measured by the percentage of the firm owned by the state. "Unionization" which is measured by the percentage of labor force unionized.

Most of the network variables employed, such as joint venture, chamber of commerce, foreign financing and participations directly relate to networks. Some other variables relate to network more indirectly and would also relate to other important economic factors such as technology, institution, culture, and so on. For instance, "E-mail" and "website" may be interpreted as technology variables that reduce the fixed cost of gathering information; but fixed costs are reduced precisely because this technology allows firms to be part of a network (the web). Another example is "Time spent with gov't regulations" which may be a function of the country institutional and regulatory environment; however, once controlling for country-industry fixed effects, the residual effect at the firm level is likely to reflect the role firms' network connections useful to penetrate heavily regulated markets or mar-

\footnotetext{
${ }^{2}$ See, for example, Helpman et al. (2004), Eaton et al. (2008), and the survey offered by Wagner (2007).
} 
kets upon which governments have a large influence. Another example is "Unionization" which is a network of workers reflecting labor market institutions and regulations, and often presenting a negative externality for the firm. What all these variable have in common is that they can all be related to networking.

In order to gauge the overall effect of network connections (beyond that of any single variable) we construct a synthetic index of all variables that can directly or indirectly characterize a network connection. We name it "network index". Such network index is the sum of all network variables after they are standardized (i.e. demeaned, and divided by their standard deviation), and the sign of each component is adjusted to reflect a positive effect on the probability of exporting. Only the sign of two variables is changed before summing them (the percentage of workforce unionized and state participation), as these two variables tend to appear with a negative sign, and presumably characterize costs or frictions. For convenience, the network variable is normalized (zero mean and standard deviation equal to 1).

For each underlying variable, we carefully check the data for extreme values (dropping few firms whose employment or sales would be reported as larger than national aggregate indicators at the country level available in standard macroeconomic databases such as World Bank or IFS), consistency checks (dropping firms where reported categories of employment would not add up to total reported firm employment, or reported categories of capital would not add up to total reported firm capital), and for outliers (observations deviating from the country-industry mean by more than three standard deviations, in log terms). After data cleanup, our data set encompasses about 8,000 firms in 24 industries and 32 countries. $^{3}$ Summary statistics for the

\footnotetext{
${ }^{3}$ The industries in our sample are: Textiles; Leather; Garments; Agroindustry; Food; Beverages; Metals and machinery; Electronics; Chemicals and pharmaceutical; Construction; Wood and furniture; Non-metallic and plastic materials; Paper; Sport goods; IT services; Other manufacturing; Accounting and finance; Advertising and marketing; Other services; Retail and wholesale trade; Transport; Mining and quarrying; Auto and auto components; Other transport equipment. The countries in the sample (with the respective year of survey) are: Algeria 2002; Bangladesh 2002; Chile 2004; China 2003; Ecuador 2003; Egypt 2004; El Salvador 2003; Ethiopia 2002; Guatemala 2003; Honduras 2003; In-
} 
variables used are in Table 3.

[TABLE 3 HERE]

\section{Empirical results.}

The effect of productivity, size and network connections on the probability of exporting is explored in Tables 4, 5 and 6 .

Table 4 uses OLS to check the contribution of each set of variables to the variability of the export dummy. Country effects have a stronger explanatory power than sector effects (with an $R^{2}$ of about 13 percent and 7 percent respectively). Both country and industry effects have an explanatory power close to the sum of the two effects separately. With country-industry effects, the $R^{2}$ rises to about 27 percent. Productivity variables and network variables, when entered alone, have a similar explanatory power (17 percent versus 15 percent respectively). When all variables enter the regression, the $R^{2}$ is about 36 percent. Replacing all network variables with the synthetic network index implies only a minimal reduction in explanatory power (the $R^{2}$ is about 35 percent).

[TABLE 4 HERE.]

Tables 5 and 6 show probit regressions of the export dummy on productivity, size, and networks variables. ${ }^{4}$ In Table 5 robust standard errors are employed, while in Table 6 we cluster errors by country and industry and results are unchanged. The Tables show that both firms' productivity and firms' size have a positive and significant effect which confirms results well established in the literature. The tables also show importance of the explanatory variables related to various forms of firms' connections to networks (the following effects are based on the first column of these tables, when all variables are si-

dia 2000; Kosovo 2003; Kyrgyzstan 2003; Lithuania 2004; Madagascar 2005; Malawi 2005; Mauritius 2005; Morocco 2004; Nicaragua 2003; Pakistan 2002; Philippines 2003; Poland 2003; Serbia 2003; South Africa 2003; Sri Lanka 2004; Tajikistan 2003; Tanzania 2003; Thailand 2004; Turkey 2005; Uzbekistan 2003; Vietnam 2005; Zambia 2002.

${ }^{4}$ The coefficients in the tables with probit regressions represent marginal effect, i.e. the change in the probability for an infinitesimal change in each independent, continuous variable. 
multaneously included). Firms' foreign connections are all positively related to the probability of exporting: an increase in Foreign financing or Foreign participation by $10 \%$ is associated with a $3 \%$ and $2 \%$ (respectively) increase in the probability of exporting, while firms with a Foreign joint venture are $16 \%$ more likely to export. Firms are also more likely to export if they have more advanced communication technologies (firms employing E-mail or websites are associated with a $14 \%$ or $7 \%$ higher probability of exporting, respectively), or stronger domestic connections (firms which are member of a chamber of commerce are associated with a $13 \%$ higher probability of exporting) or by the time spent with government regulations (a 10\% larger share of senior management's time spent dealing with government regulations is associated with a $2 \%$ higher probability of exporting). Younger firms tend to be associated with a higher export probability (every additional 10 years of existence are associated with a $2 \%$ decrease in the probability of exporting). ${ }^{5}$ Lastly, firms affected by state or labor networks tend to export less: a $10 \%$ increase in state participation is associated with a $3 \%$ lower probability of exporting; the effect of unionization is very small when controlling for all variables (in column 1 of both table 5 and 6), but in column 12 of both tables a $10 \%$ increase in state participation is associated with a $1 \%$ lower probability of exporting). ${ }^{6}$ Overall, an improvement the network index by one standard deviation is associated with a higher probability of exporting of about $15 \%$.

\section{[TABLE 5 and 6 HERE]}

\footnotetext{
${ }^{5}$ As fixed effects control for the (slight) difference in years of the survey across countries, the variable related to "Year firm began operations", is automatically equivalent to the opposite of the age of the firm. Note that this result is in contrast with the literature on advanced economies (see for example Barba Navaretti et al., 2010), where older firms are more likely to export, and may reflect the more vibrant nature of the countries in our sample.

${ }^{6}$ The variables "Firms is in a joint venture", "Firms uses E-mail", "Firm has website", and "Firm belongs to a chamber of commerce", are dummy variables: 1 if the firm does, 0 otherwise. "Foreign financing" is measured by the percentage of working capital financed by foreign-owned banks. "Foreign participation" is measured by the percentage of the firm owned by foreign private sector. "Time spent with gov't regulations" is measured by the percentage of senior management's time spend dealing with government regulations. "State participation" is measured by measured by the percentage of the firm owned by the state. "Unionization" is measured by the percentage of labor force unionized.
} 


\section{Conclusions.}

What determines the export performance of firms? Recent theoretical developments in the trade literature point at productivity as a key determinants, while a separate strand of literature has highlighted over the past decade the importance of networking connections. The empirical literature has extensively documented the importance of productivity for the export performance of firms, while evidence of the role of networks is very limited. This paper makes use of a cross-country and multi-sector firm level data to jointly confirm these theories. We find that firms are more likely to export if they are more productive and larger, but also if they benefit from foreign networks (financial, ownership, or joint-venture links), domestic networks (chamber of commerce, links to regulation), and communication networks (E-mail, Website), while their export performance suffers from state and labor networks (government participation or unionization). 


\section{References}

[1] Aitken Brian, Gordon H. Hanson, Ann E. Harrison (1997) "Spillovers, foreign investment, and export behavior" Journal of international economics 43: 103-132.

[2] Bernard, Andrew B., Eaton, Jonathan, Jensen, J. Bradford, and Kortum, Samuel (2003) "Plants and Productivity in International Trade." American Economic Review, 93: 1268-1290.

[3] Bernard, Andrew B. and J. Bradford Jensen (1999). "Exceptional Exporter Performance: Cause, Effect, or Both." Journal of International Economics 47: 1-25.

[4] Bernard B. Andrew and J. Bradford Jensen (2004). "Why Some Firms Export." Review of Economics and Statistics 86: 561-569.

[5] Casella, A. and Rauch, J. (2002) 'Anonymous market and group ties in international trade', Journal of International Economics, vol. 58(1), pp. $19-47$.

[6] Combes, Pierre-Philippe, Lafourcade Mirene, and Mayer Thierry. (2005) "The trade creating effects of business and social networks: evidence from France" Journal of International Economics 66:1-29.

[7] Eaton, Jonathan, Samuel Kortum, and Francis Kramarz (2008) "An Anatomy of International Trade: Evidence from French Firms." Econometrica, forthcoming.

[8] Helpman Elhanan, Marc J. Melitz, Stephen R. Yeaple (2004) "Export Versus FDI with Heterogeneous Firms" American Economic Review 94(1):300-316.

[9] Melitz J. Marc (2003) "The impact of trade on intra-industry reallocations and aggregate industry productivity". Econometrica 71(6):16951725 . 
[10] Rauch, James (2001) "Business and social networks in international trade" Journal of Economic Literature 39,1177- 1203.

[11] Rauch, James and Casella Alessandra (2003) "Overcoming Informational Barrieres to International resource Allocation: Prices and Ties" The Economic Journal 113: 21-42.

[12] Rauch, J., Trindade, V. (2002) "Ethnic Chinese networks in international trade" Review of Economics and Statistics 84 (1), 116- 130.

[13] Roberts M. and J. Tybout (1997) "The Decision to Export in Colombia: An Empirical Model of Entry with Sunk Costs," , American Economic Review 87(4): 545-563.

[14] Rodrik Dani (2000) "How Far Will International Economic Integration Go?" Journal of Economic Perspectives 14(1):177-186.

[15] Wagner, D., Head, K., Ries, J., 2002. Immigration and the trade of provinces. Scottish Journal of Political Economy 49 (5), 507-525. 
Table 1

PERCENTAGE OF FIRMS THAT EXPORTS BY COUNTRY

\begin{tabular}{lcccc}
\hline \hline SIZE & 1 & 2 & 3 & TOTAL \\
number employees $\rightarrow$ & $1-24$ & $25-99$ & $100+$ & ALL \\
\hline Algeria2002 & $0 \%$ & $0 \%$ & $4 \%$ & $1 \%$ \\
Bangladesh2002 & $7 \%$ & $23 \%$ & $36 \%$ & $30 \%$ \\
Chile2004 & $10 \%$ & $26 \%$ & $53 \%$ & $30 \%$ \\
China2003 & $4 \%$ & $0 \%$ & $6 \%$ & $4 \%$ \\
Ecuador2003 & $10 \%$ & $22 \%$ & $40 \%$ & $22 \%$ \\
Egypt2004 & $4 \%$ & $20 \%$ & $41 \%$ & $17 \%$ \\
ElSalvador2003 & $5 \%$ & $43 \%$ & $70 \%$ & $35 \%$ \\
Ethiopia2002 & $0 \%$ & $19 \%$ & $8 \%$ & $8 \%$ \\
Guatemala2003 & $11 \%$ & $35 \%$ & $70 \%$ & $31 \%$ \\
Honduras2003 & $6 \%$ & $24 \%$ & $69 \%$ & $19 \%$ \\
India2000 & $47 \%$ & $58 \%$ & $67 \%$ & $60 \%$ \\
Kosovo2003 & $0 \%$ & $17 \%$ & $0 \%$ & $4 \%$ \\
Kyrgyzstan2003 & $7 \%$ & $17 \%$ & $25 \%$ & $15 \%$ \\
Lithuania2004 & $11 \%$ & $42 \%$ & $68 \%$ & $47 \%$ \\
Madagascar2005 & $0 \%$ & $0 \%$ & $75 \%$ & $69 \%$ \\
Malawi2005 & $0 \%$ & $35 \%$ & $44 \%$ & $36 \%$ \\
Mauritius2005 & $0 \%$ & $33 \%$ & $67 \%$ & $40 \%$ \\
Morocco2004 & $21 \%$ & $39 \%$ & $71 \%$ & $50 \%$ \\
Nicaragua2003 & $4 \%$ & $27 \%$ & $46 \%$ & $12 \%$ \\
Pakistan2002 & $8 \%$ & $10 \%$ & $25 \%$ & $10 \%$ \\
Philippines2003 & $6 \%$ & $17 \%$ & $60 \%$ & $35 \%$ \\
Poland2003 & $6 \%$ & $17 \%$ & $45 \%$ & $20 \%$ \\
Serbia2003 & $17 \%$ & $14 \%$ & $20 \%$ & $17 \%$ \\
SouthAfrica2003 & $29 \%$ & $38 \%$ & $54 \%$ & $46 \%$ \\
SriLanka2004 & $10 \%$ & $23 \%$ & $52 \%$ & $38 \%$ \\
Tajikistan2003 & $0 \%$ & $0 \%$ & $0 \%$ & $0 \%$ \\
Tanzania2003 & $26 \%$ & $31 \%$ & $46 \%$ & $33 \%$ \\
Thailand2004 & $19 \%$ & $40 \%$ & $70 \%$ & $61 \%$ \\
Turkey-b2005 & $16 \%$ & $39 \%$ & $65 \%$ & $47 \%$ \\
Uzbekistan2003 & $6 \%$ & $0 \%$ & $0 \%$ & $2 \%$ \\
Vietnam2005 & $7 \%$ & $20 \%$ & $50 \%$ & $35 \%$ \\
Zambia2002 & $21 \%$ & $18 \%$ & $51 \%$ & $31 \%$ \\
\hline ALL countries & $8 \%$ & $25 \%$ & $51 \%$ & $31 \%$ \\
\hline
\end{tabular}


Table 2

PERCENTAGE OF FIRMS THAT EXPORTS BY INDUSTRY

\begin{tabular}{lcccc}
\hline \hline SIZE & 1 & 2 & 3 & TOTAL \\
number employees $\rightarrow$ & $1-24$ & $25-99$ & $100+$ & ALL \\
\hline Textiles & $7 \%$ & $22 \%$ & $46 \%$ & $30 \%$ \\
Leather & $10 \%$ & $57 \%$ & $75 \%$ & $46 \%$ \\
Garments & $11 \%$ & $39 \%$ & $80 \%$ & $55 \%$ \\
Agroindustry & $23 \%$ & $27 \%$ & $56 \%$ & $38 \%$ \\
Food & $7 \%$ & $24 \%$ & $43 \%$ & $26 \%$ \\
Beverages & $6 \%$ & $14 \%$ & $11 \%$ & $10 \%$ \\
Metals and machinery & $7 \%$ & $26 \%$ & $47 \%$ & $28 \%$ \\
Electronics & $15 \%$ & $16 \%$ & $62 \%$ & $43 \%$ \\
Chemicals and pharmaceutics & $10 \%$ & $20 \%$ & $33 \%$ & $22 \%$ \\
Construction & $7 \%$ & $7 \%$ & $10 \%$ & $8 \%$ \\
Wood and furniture & $4 \%$ & $26 \%$ & $62 \%$ & $26 \%$ \\
Non-metallic and plastic materials & $9 \%$ & $21 \%$ & $43 \%$ & $24 \%$ \\
Paper & $5 \%$ & $10 \%$ & $31 \%$ & $18 \%$ \\
Sport goods & $45 \%$ & $100 \%$ & $100 \%$ & $63 \%$ \\
IT services & $8 \%$ & $11 \%$ & $7 \%$ & $9 \%$ \\
Other manufacturing & $10 \%$ & $24 \%$ & $34 \%$ & $26 \%$ \\
Accounting and finance & $0 \%$ & $0 \%$ & $0 \%$ & $0 \%$ \\
Advertising and marketing & $0 \%$ & $0 \%$ & $0 \%$ & $0 \%$ \\
Other services & $0 \%$ & $0 \%$ & $0 \%$ & $0 \%$ \\
Retail and wholesale trade & $0 \%$ & $100 \%$ & & $8 \%$ \\
Transport & $0 \%$ & $0 \%$ & & $0 \%$ \\
Mining and quarrying & $50 \%$ & $0 \%$ & $83 \%$ & $55 \%$ \\
Auto and auto components & $17 \%$ & $19 \%$ & $21 \%$ & $20 \%$ \\
Other transport equipment & $40 \%$ & $56 \%$ & $63 \%$ & $55 \%$ \\
\hline & & & & \\
ALL sectors & $8 \%$ & $25 \%$ & $51 \%$ & $31 \%$ \\
& & & &
\end{tabular}


Table 3

Summary Statistics

\begin{tabular}{lrrrrr}
\hline \hline Variable & Obs & Mean & Std. Dev. & Min & Max \\
\hline Firm is an exporter $^{(1)}$ & 7862 & 0.31 & 0.46 & 0.00 & 1 \\
Log of productivity $^{(1)}$ & 7862 & 9.76 & 2.17 & -5.72 & 20.81 \\
Log of employment $^{(1)}$ & 7862 & 4.30 & 1.55 & 0.69 & 11.13 \\
Foreign financing $^{(2)}$ & 7430 & 1.03 & 7.53 & 0.00 & 100 \\
Firm is in a joint venture with a foreign partner $^{(1)}$ & 5737 & 0.07 & 0.26 & 0.00 & 1 \\
Foreign participation $^{(3)}$ & 7815 & 9.98 & 27.63 & 0.00 & 100 \\
Firm uses email $^{(1)}$ & 7409 & 0.62 & 0.49 & 0.00 & 1 \\
Firm has website $^{(1)}$ & 7291 & 0.35 & 0.48 & 0.00 & 1 \\
Firm belongs to a chamber of commerce $^{(1)}$ & 6041 & 0.67 & 0.47 & 0.00 & 1 \\
Time spent with gov't regulations $^{(4)}$ & 6102 & 8.78 & 13.70 & 0.00 & 100 \\
State participation $^{(5)}$ & 7815 & 6.32 & 22.56 & 0.00 & 100 \\
Unionization $^{(6)}$ & 7246 & 19.06 & 35.30 & 0.00 & 100 \\
Year firm began operations $^{(7)}$ Network index $^{\left({ }^{(1)}\right.}$ & 6938 & 1983 & 18 & 1838 & 2004 \\
\hline
\end{tabular}

(1) Dummy variable: 1 if the firm does, 0 Otherwise.

(2) Percentage finance for working capital: foreign-owned banks;

(3) Percentage of firm owned by foreign private sector;

(4) Percentage of senior management's time spent dealing with government regulations;

(5) Percentage of firm owned by the state

(6) Percentage of labor force unionized.

(7) See text for definition. 
TABLE 4

OLS regression of the export dummy on fundamentals controlling for country*industry effects

\begin{tabular}{|c|c|c|c|c|c|c|c|c|c|c|c|c|c|}
\hline VARIABLES & $\begin{array}{c}1 \\
C E\end{array}$ & $\begin{array}{l}2 \\
\mathrm{IE}\end{array}$ & $\begin{array}{c}3 \\
\text { CE IE }\end{array}$ & $\begin{array}{c}4 \\
C * I E\end{array}$ & $\begin{array}{c}5 \\
C * \mid E\end{array}$ & $\begin{array}{c}6 \\
C * I E\end{array}$ & $\begin{array}{c}7 \\
C * I E\end{array}$ & $\begin{array}{c}8 \\
C * I E\end{array}$ & $\begin{array}{c}9 \\
C^{*} \mid E\end{array}$ & $\begin{array}{c}10 \\
\text { none }\end{array}$ & $\begin{array}{c}11 \\
\text { none }\end{array}$ & $\begin{array}{c}12 \\
\text { none }\end{array}$ & $\begin{array}{c}13 \\
\text { none }\end{array}$ \\
\hline Log of productivity & & & & & $\begin{array}{c}0.049 \\
(0.000)^{\star \star \star}\end{array}$ & & $\begin{array}{c}0.036 \\
(0.000)^{\star \star \star}\end{array}$ & $\begin{array}{c}0.034 \\
(0.000)^{\star \star \star \star}\end{array}$ & $\begin{array}{c}0.038 \\
\star(0.000)^{\star \star \star *}(\end{array}$ & $\begin{array}{c}0.012 \\
(0.000)^{\star \star \star}\end{array}$ & & $\begin{array}{c}0.02 \\
(0.002)^{\star \star \star}\end{array}$ & $\begin{array}{c}0.021 \\
(0.001)^{\star \star \star}\end{array}$ \\
\hline Log of employment & & & & & & $\begin{array}{c}0.106 \\
(0.000)^{\star \star \star}\end{array}$ & $\begin{array}{c}0.102 \\
*(0.000)^{\star \star \star}\end{array}$ & $\begin{array}{c}0.087 \\
(0.000)^{\star \star \star \star}\end{array}$ & $\begin{array}{c}0.099 \\
\star(0.000)^{\star \star \star *}(\end{array}$ & $\begin{array}{c}0.122 \\
(0.000)^{\star \star \star}\end{array}$ & & $\begin{array}{c}0.125 \\
(0.000)^{\star \star \star}\end{array}$ & $\begin{array}{c}0.131 \\
(0.000)^{\star \star \star}\end{array}$ \\
\hline Foreign financing & & & & & & & & $\begin{array}{c}0.002 \\
(0.031)^{\star \star}\end{array}$ & & & $\begin{array}{c}0.002 \\
-0.124\end{array}$ & $\begin{array}{r}0.002 \\
-0.161\end{array}$ & \\
\hline Foreign joint venture & & & & & & & & $\begin{array}{c}0.106 \\
(0.001)^{\star \star \star}\end{array}$ & & & $\begin{array}{c}0.084 \\
(0.015)^{\star \star}\end{array}$ & $\begin{array}{c}0.065 \\
* \quad(0.051)^{*}\end{array}$ & \\
\hline Foreign participation & & & & & & & & $\begin{array}{c}0.002 \\
(0.000)^{\star \star \star}\end{array}$ & & & $\begin{array}{c}0.003 \\
(0.000)^{\star * *}\end{array}$ & $\begin{array}{c}0.001 \\
*(0.000)^{\star \star * \star}\end{array}$ & \\
\hline Firm uses Email & & & & & & & & $\begin{array}{c}0.088 \\
(0.000)^{\star \star \star}\end{array}$ & & & $\begin{array}{c}0.108 \\
(0.000)^{\star * *}\end{array}$ & $\begin{array}{c}0.062 \\
*(0.006)^{\star \star \star *}\end{array}$ & \\
\hline Firm has website & & & & & & & & $\begin{array}{c}0.053 \\
(0.013)^{\star \star}\end{array}$ & & & $\begin{array}{c}0.083 \\
(0.000)^{\star \star \star *}\end{array}$ & $\begin{array}{l}0.029 \\
* \quad-0.17\end{array}$ & \\
\hline Firm part of chamber of commerce & & & & & & & & $\begin{array}{c}0.092 \\
(0.000)^{\star \star \star}\end{array}$ & & & $\begin{array}{c}0.188 \\
(0.000)^{\star \star \star}\end{array}$ & $\begin{array}{c}0.083 \\
*(0.000)^{\star \star \star}\end{array}$ & \\
\hline Time spent with gov't regulations & & & & & & & & $\begin{array}{c}0.001 \\
(0.039)^{\star \star}\end{array}$ & & & $\begin{array}{c}-0.001 \\
(0.060)^{\star}\end{array}$ & $\begin{array}{c}0 \\
-0.64\end{array}$ & \\
\hline State participation & & & & & & & & $\begin{array}{c}-0.002 \\
(0.008)^{\star \star \star}\end{array}$ & & & $\begin{array}{c}-0.002 \\
(0.021)^{\star \star}\end{array}$ & $\begin{array}{c}-0.002 \\
(0.048)^{\star *}\end{array}$ & \\
\hline Unionization & & & & & & & & $\begin{array}{c}0 \\
-0.365\end{array}$ & & & $\begin{array}{c}0 \\
-0.212\end{array}$ & $\begin{array}{c}0 \\
-0.299\end{array}$ & \\
\hline Year firm began operations & & & & & & & & $\begin{array}{c}0.002 \\
(0.001)^{\star \star \star}\end{array}$ & & & $\begin{array}{c}0.002 \\
(0.000)^{\star * *}\end{array}$ & $\begin{array}{c}0.003 \\
*(0.000)^{\star \star * \star}\end{array}$ & \\
\hline Network index & & & & & & & & & $\begin{array}{c}0.11 \\
(0.000)^{\star \star \star}\end{array}$ & & & & $\begin{array}{c}0.09 \\
(0.000)^{\star \star \star}\end{array}$ \\
\hline Constant & $\begin{array}{c}0.01 \\
-0.316\end{array}$ & $\begin{array}{c}0.296 \\
(0.000)^{\star \star \star}\end{array}$ & $\begin{array}{c}0.052 \\
(0.007)^{\star \star \star}\end{array}$ & $\begin{array}{c}0.511 \\
(0.000)^{\star \star \star}\end{array}$ & $\begin{array}{r}0.001 \\
-0.987\end{array}$ & $\begin{array}{l}-0.059 \\
-0.412\end{array}$ & $\begin{array}{c}-0.414 \\
(0.000)^{\star \star \star}\end{array}$ & $\begin{array}{c}-4.342 \\
(0.000)^{\star \star \star}\end{array}$ & $\begin{array}{l}-0.784 \\
\star(0.000)^{\star \star \star}(\end{array}$ & $\begin{array}{c}-0.324 \\
(0.000)^{\star \star \star}\end{array}$ & $\begin{array}{l}-3.843 \\
(0.000)^{\star \star \star}\end{array}$ & $\begin{array}{c}-6.101 \\
\star(0.000)^{\star \star \star}\end{array}$ & $\begin{array}{c}-0.388 \\
(0.000)^{\star \star \star}\end{array}$ \\
\hline $\begin{array}{l}\text { Observations } \\
\text { R-squared }\end{array}$ & $\begin{array}{l}7963 \\
0.13\end{array}$ & $\begin{array}{l}7963 \\
0.07\end{array}$ & $\begin{array}{l}7963 \\
0.19\end{array}$ & $\begin{array}{l}7963 \\
0.27\end{array}$ & $\begin{array}{l}7862 \\
0.28\end{array}$ & $\begin{array}{l}7963 \\
0.35\end{array}$ & $\begin{array}{l}7862 \\
0.36\end{array}$ & $\begin{array}{l}2356 \\
0.36\end{array}$ & $\begin{array}{l}2356 \\
0.35\end{array}$ & $\begin{array}{l}7862 \\
0.17\end{array}$ & $\begin{array}{l}2379 \\
0.15\end{array}$ & $\begin{array}{l}2356 \\
0.27\end{array}$ & $\begin{array}{l}2356 \\
0.25\end{array}$ \\
\hline $\begin{array}{l}\text { Robust } p \text {-values in parentheses } \\
{ }^{* \star *} p<0.01,{ }^{* *} p<0.05,{ }^{*} p<0.1\end{array}$ & & & $\begin{array}{ll}\mathrm{CE} & =\mathrm{c} \\
\mathrm{IE} & =\text { in }\end{array}$ & $\begin{array}{l}\text { country effe } \\
\text { ndustry effe }\end{array}$ & ects & & $\begin{array}{l}\text { CE IE }=c \\
C^{*} I E=C\end{array}$ & $\begin{array}{l}\text { country eff } \\
\text { country/ind }\end{array}$ & $\begin{array}{l}\text { fects +indu } \\
\text { dustry effec }\end{array}$ & $\begin{array}{l}\text { ustry effec } \\
\text { cts }\end{array}$ & & & \\
\hline
\end{tabular}


TABLE 5

Probit regression of the export dummy on fundamentals controlling for country*industry effects

\begin{tabular}{|c|c|c|c|c|c|c|c|c|c|c|c|c|c|}
\hline VARIABLES & 1 & 2 & 3 & 4 & 5 & 6 & 7 & 8 & 9 & 10 & 11 & 12 & 13 \\
\hline \multirow[t]{2}{*}{ Log of productivity } & 0.06 & 0.051 & 0.055 & 0.046 & 0.05 & 0.04 & 0.046 & 0.052 & 0.051 & 0.054 & 0.049 & 0.052 & 0.064 \\
\hline & $(0.000)^{\star \star \star}$ & $(0.000)^{\star \star \star}$ & $(0.000)^{\star \star \star}($ & $(0.000)^{\star \star \star}($ & ${ }^{*}(0.000)^{\star \star \star}($ & ${ }^{\star}(0.000)^{\star \star \star}$ & $(0.000)^{\star \star \star}($ & $\star(0.000)^{\star \star \star}($ & $(0.000)^{\star \star \star}$ & $\star(0.000)^{\star \star *}($ & $(0.000)^{\star \star \star}($ & ${ }^{\star}(0.000)^{\star \star \star}$ & $\star(0.000)^{\star \star \star}$ \\
\hline \multirow[t]{2}{*}{ Log of employment } & 0.119 & 0.128 & 0.137 & 0.123 & 0.135 & 0.11 & 0.121 & 0.111 & 0.129 & 0.134 & 0.147 & 0.142 & 0.135 \\
\hline & $(0.000)^{\star \star \star}$ & $(0.000)^{\star \star \star}$ & $(0.000)^{\star \star \star}($ & $(0.000)^{\star \star \star}($ & $\star(0.000)^{\star \star \star}($ & $\star(0.000)^{\star \star \star}$ & $(0.000)^{\star \star \star}($ & *(0.000) $)^{\star \star \star}($ & $(0.000)^{\star \star \star}$ & *(0.000)***( & $(0.000)^{\star \star \star}$ & $\star(0.000)^{\star \star \star}$ & 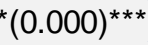 \\
\hline Foreign Financing & $\begin{array}{c}0.003 \\
(0.023)^{\star \star}\end{array}$ & & $\begin{array}{c}0.004 \\
(0.000)^{\star \star \star}\end{array}$ & & & & & & & & & & \\
\hline Foreign Joint Venture & $\begin{array}{c}0.159 \\
(0.001)^{\star \star \star}\end{array}$ & & & $\begin{array}{c}0.13 \\
(0.000)^{\star \star \star}\end{array}$ & & & & & & & & & \\
\hline Foreign Participation & $\begin{array}{c}0.002 \\
(0.000)^{\star \star \star}\end{array}$ & & & & $\begin{array}{c}0.002 \\
(0.000)^{\star \star \star}\end{array}$ & & & & & & & & \\
\hline Firm uses Email & $\begin{array}{c}0.14 \\
(0.000)^{\star \star \star}\end{array}$ & & & & & $\begin{array}{c}0.201 \\
(0.000)^{\star \star \star}\end{array}$ & & & & & & & \\
\hline Firm has Website & $\begin{array}{c}0.067 \\
(0.016)^{\star \star}\end{array}$ & & & & & & $\begin{array}{c}0.131 \\
(0.000)^{\star \star \star}\end{array}$ & & & & & & \\
\hline Firm part of Chamber of Commerce & $\begin{array}{c}0.128 \\
(0.000)^{\star \star \star}\end{array}$ & & & & & & & $\begin{array}{c}0.093 \\
(0.000)^{\star \star \star}\end{array}$ & & & & & \\
\hline Time spent with gov't regulations & $\begin{array}{c}0.002 \\
(0.014)^{\star \star}\end{array}$ & & & & & & & & $\begin{array}{c}0.001 \\
(0.021)^{\star \star}\end{array}$ & & & & \\
\hline State Participation & $\begin{array}{c}-0.003 \\
(0.029)^{\star \star}\end{array}$ & & & & & & & & & $\begin{array}{c}-0.002 \\
(0.000)^{\star \star \star}\end{array}$ & & & \\
\hline Percentage of workforce unionized & $\begin{array}{c}0 \\
-0.359\end{array}$ & & & & & & & & & & $\begin{array}{c}-0.001 \\
(0.000)^{\star \star \star}\end{array}$ & & \\
\hline Year firm began operations & $\begin{array}{c}0.002 \\
(0.001)^{\star \star \star}\end{array}$ & & & & & & & & & & & $\begin{array}{c}0.003 \\
(0.000)^{\star \star \star}\end{array}$ & \\
\hline Network index & & & & & & & & & & & & & $\begin{array}{c}0.155 \\
(0.000)^{\star \star \star}\end{array}$ \\
\hline Observations & 2311 & 7526 & 6591 & 7422 & 7422 & 7183 & 7067 & 5733 & 7198 & 5859 & 5643 & 7064 & 2311 \\
\hline Pseudo R2: & 0.314 & 0.315 & 0.308 & 0.323 & 0.316 & 0.335 & 0.323 & 0.339 & 0.322 & 0.315 & 0.291 & 0.312 & 0.308 \\
\hline
\end{tabular}


TABLE 6

Probit regression of the export dummy on fundamentals controlling for country*industry effects: errors clustered at country*industry level

\begin{tabular}{|c|c|c|c|c|c|c|c|c|c|c|c|c|c|}
\hline VARIABLES & 1 & 2 & 3 & 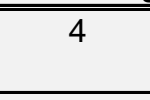 & $\bar{~} 5$ & 6 & 7 & 8 & 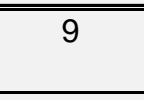 & $\bar{~} 10$ & 11 & $\overline{12}$ & 13 \\
\hline \multirow[t]{2}{*}{ Log of productivity } & 0.06 & 0.051 & 0.055 & 0.046 & 0.05 & 0.04 & 0.046 & 0.052 & 0.051 & 0.054 & 0.049 & 0.052 & 0.064 \\
\hline & $(0.000)^{\star \star \star}$ & $(0.000)^{\star \star \star}$ & $(0.000)^{\star \star \star}$ & $\star(0.000)^{\star \star \star}$ & ${ }^{*}(0.000)^{\star \star \star}($ & $(0.000)^{\star \star \star}($ & $(0.000)^{\star \star \star}($ & $(0.000)^{\star \star \star}$ & $(0.000)^{\star \star \star}$ & $\star(0.000)^{\star \star \star}($ & $(0.000)^{\star \star \star}($ & $(0.000)^{\star \star \star}($ & $(0.000)^{\star \star \star}$ \\
\hline \multirow[t]{2}{*}{ Log of employment } & 0.119 & 0.128 & 0.137 & 0.123 & 0.135 & 0.11 & 0.121 & 0.111 & 0.129 & 0.134 & 0.147 & 0.142 & 0.135 \\
\hline & $(0.000)^{\star \star \star}$ & $(0.000)^{\star \star \star}$ & $(0.000)^{\star \star \star}$ & $\star(0.000)^{\star \star \star}$ & $\star(0.000)^{\star \star \star}($ & $(0.000)^{\star \star \star}($ & $(0.000)^{\star \star \star}($ & $(0.000) \star \star \star *($ & $(0.000)^{\star \star \star}$ & ${ }^{\star}(0.000)^{\star \star \star}(($ & $(0.000)^{\star \star \star}($ & $(0.000)^{\star \star \star}($ & $(0.000)^{\star \star \star}$ \\
\hline Foreign financing & $\begin{array}{c}0.003 \\
(0.038)^{\star \star}\end{array}$ & & $\begin{array}{c}0.004 \\
(0.000)^{\star \star \star}\end{array}$ & & & & & & & & & & \\
\hline Foreign joint venture & $\begin{array}{c}0.159 \\
(0.001)^{\star \star \star}\end{array}$ & & & $\begin{array}{c}0.13 \\
(0.000)^{\star \star \star}\end{array}$ & & & & & & & & & \\
\hline Foreign participation & $\begin{array}{c}0.002 \\
(0.000)^{\star \star \star}\end{array}$ & & & & $\begin{array}{c}0.002 \\
(0.000)^{\star \star \star}\end{array}$ & & & & & & & & \\
\hline Firm uses Email & $\begin{array}{c}0.14 \\
(0.004)^{\star \star \star}\end{array}$ & & & & & $\begin{array}{c}0.201 \\
(0.000)^{\star \star \star}\end{array}$ & & & & & & & \\
\hline Firm has website & $\begin{array}{c}0.067 \\
(0.019)^{\star \star}\end{array}$ & & & & & & $\begin{array}{c}0.131 \\
(0.000)^{\star \star \star}\end{array}$ & & & & & & \\
\hline Firm part of chamber of commerce & $\begin{array}{c}0.128 \\
(0.000)^{\star \star \star}\end{array}$ & & & & & & & $\begin{array}{c}0.093 \\
(0.000)^{\star \star \star}\end{array}$ & & & & & \\
\hline Time spent with gov't regulations & $\begin{array}{c}0.002 \\
(0.033)^{\star \star}\end{array}$ & & & & & & & & $\begin{array}{c}0.001 \\
(0.028)^{\star \star}\end{array}$ & & & & \\
\hline State participation & $\begin{array}{c}-0.003 \\
(0.012)^{\star \star}\end{array}$ & & & & & & & & & $\begin{array}{c}-0.002 \\
(0.002)^{\star \star \star}\end{array}$ & & & \\
\hline Unionization & $\begin{array}{c}0 \\
-0.394\end{array}$ & & & & & & & & & & $\begin{array}{c}-0.001 \\
(0.000)^{\star \star \star}\end{array}$ & & \\
\hline Year firm began operations & $\begin{array}{c}0.002 \\
(0.001)^{\star \star \star}\end{array}$ & & & & & & & & & & & $\begin{array}{c}0.003 \\
(0.000)^{\star \star \star}\end{array}$ & \\
\hline Network index & & & & & & & & & & & & & $\begin{array}{c}0.155 \\
(0.000)^{\star \star \star}\end{array}$ \\
\hline Observations & 2311 & 7526 & 6591 & 7422 & 7422 & 7183 & 7067 & 5733 & 7198 & 5859 & 5643 & 7064 & 2311 \\
\hline Pseudo R2: & 0.314 & 0.315 & 0.308 & 0.323 & 0.316 & 0.335 & 0.323 & 0.339 & 0.322 & 0.315 & 0.291 & 0.312 & 0.308 \\
\hline
\end{tabular}

Robust $\mathrm{p}$-values in parentheses

${ }^{\star * \star} p<0.01,{ }^{* \star} p<0.05,{ }^{*} p<0.1$ 